\author{
Lukman Olorogun, \\ Ph.D., Business Department, \\ Higher Colleges of Technology, \\ Abu Dhabi, United Arab Emirates \\ Nasir Yunusa, \\ Ph.D., Department of Accounting, \\ Ahmadu Bello University Zaria, \\ Zaria, Nigeria \\ Hauwa Galadima Audu, \\ Sultan Abdul Halim Mu'adzam Shah International \\ Islamic University, \\ Kedah, Malaysia \\ Adam Andani Mohammed \\ Ph.D., University Malaysia Sarawak \\ Sarawak, Malaysia
}

\title{
MANAGEMENT OF EDUCATIONAL INNOVATIONS: EFFECTS OF INFUSING "CRITICAL THINKING" INTO ISLAMIC FINANCE CURRICULA
}

Shortage of human capital has been identified in the Islamic financial industry. It is believed that the infusion of critical thinking would boost the students' level of professional field-related knowledge and provide them with the necessary confidence, the key to professional performance measurement. This study incorporates critical thinking into the curriculum of BWSR2013 "Risk Management and Takaful Planning". The class syllabus was divided into two sections, with each preliminary section followed by a quiz and pilot data collection, and final data collection. A SemPLS was run on SmartPLS. The results showed that lack of critical thinking in Islamic finance curricula might eventually result in a shortage of skilled professionals in the Islamic financial industry. The findings showed a great correlation between knowledge acquisition, competency and critical thinking. The students' own perceptions also indicated that the infusion of critical thinking contributed to their increased confidence (self-assurance) in the subject matter learned in this course. The results of the analysis showed that investment in teaching Islamic Finance on part with critical thinking was of utmost importance for the success of the finance industry. Competent professionals are much needed in this field and will continue to remain an unfulfilled ideal if the current system of learning and teaching Islamic Finance continues as it is. The level of confidence and self-assurance of the students can only increase if students learn how to think critically and are capable of providing solutions to real-life problems. The findings showed that the regular graduates lacked expertise also lacked confidence in their own skills. However, no significant relationship between expectation and self-assurance could be ascertained. It is recommended that this study is replicated on a large scale to vindicate the wider positive implications of critical thinking in Islamic finance training curricula.

Keywords: knowledge, perceptions, critical thinking, the Islamic finance industry, students, capabilities, curriculum.

Introduction. The competitive world of finance is witnessing a battle between secular and Islamic financial systems. A competition between substance and form, in which substance is supposed to win over form. Ideally, the substance should become the basis of competition in attracting larger market shares for ultimate profitability and social development. Thus, the consumers are spoilt for choice which challenges 
emerging Islamic financial norms and the role of institutions in setting the agenda for global Islamic finance (Maurer, 2010). Axiomatically, the conventional financial system is well-grounded in terms of theories, operations, education, and expertise, albeit nuancedly distance animates and inanimate from religious philosophy and regulations. Compare to its counterpart where human intellect presides on matters of quality, quantity, fairness, and justice; Islamic financial system is at the crossroads between fulfilling Islamic commercial laws and integrating into the global financial system. Relatively to its age, according to African Times (2018) and IFN (2018) reports that global financial and regulatory bodies such as UN, IMF, World Bank Group etc. have officially recognized Islamic finance as an essential fraction of global financial market.

The strength "arguable quality" of conventional finance, however, arise through painstaking and knowhow of its animate; particularly human efforts in all forms and fronts. Nonetheless, for mere economic and political gains. Humans, in essence, play a greater role in business success and as such worth given ardent attention. In order to advance or enhance the competitive capacity of Islamic finance in the global financial market, the crucial element constitutes human capital. Several Islamic Finance News (IFN) reports in 2015 such as Nabillah (2015a, 2015b, 2015c, 2015d) point at the acute shortage of manpower in the Islamic finance industry. One possible conclusion that can be drawn is that Islamic finance is simply less competitive compared to its conventional counterpart.

This conclusion is based on the fact that the success of a financial institution rested on the ability of its human elements to optimize all available resources in all forms and versions. Apparently, a lack of competent manpower in the key technical positions could result in a proliferation of less effective Islamic financial institutions. The type of institutions that could not maximize its stakeholders' wealth. There are shared traits between conventional and Islamic financial institutions, however, there are unique traits such as "the term stakeholders' wealth maximization" goes beyond material or worldly finite objects. Rather it includes deep comprehension of the length and breadth aspects of commercial and social dealings as dictating in Islamic laws in order to attain eternal sublimity.

Indisputably, there are enormous global efforts and inputs to overcome the shortage of required labours in all sectors. These efforts are not limited to international organizations such as International Labor Organization (ILO), UN, UNESCO etc. rather, it includes nations, corporate entities and as well as individuals (Sanz Ponce et al. 2018). Thus, reports of the acute manpower shortage are daunting, to say the least - considering the high number of academic institutions, especially universities across the world such as in Malaysia, Bahrain, U.K., Qatar, United Arab Emirates (UAE) that are presently offering Islamic finance training and development of professionals. Most of the students "customers" are non-nationals as the concentration of these institutions is currently skewed. This aligns Islamic finance education with the global educational system and its norms. In fact, the high fee-paying international students serve as a major economic resource to some of the countries that invest heavily in the education of Islamic finance professionals such as Malaysia and the U.K.

In the present study, the researcher introduced critical thinking into the syllabus of BWRS2013 "Risk Management and Takaful Planning", one of the core courses for the award of BSc in Islamic Finance and Banking at the Islamic Business School, College of Business, Universiti Utara Malaysia (UUM). Its main objective was to assess and evaluate the efficiency of the course in imparting professional know-how to the students. In this particular context, it is vital for the students to be able to synthesize between conventional insurance and Islamic Shari'ah as this would ultimately result in the much needed and much propagated "Islamization of knowledge". The substance in which Islamic insurance (Takaful) is operated according to Islamic dictates. The researcher hypothesized that the inculcation of CT skills would contribute to ending the acute shortage of competent professionals in the Islamic financial system. The introduction of CT skills could assist in ensuring that graduate students of Islamic finance and banking were more competent and more assured of their competency at all levels. The following section discusses 
the research method followed by the discussion of the result, subsequent analysis and conclusion.

Methods. As discussed in the previous section, the lack of competency in Islamic finance graduates asks for the inclusion of critical thinking in the required syllabus and for a critical assessment of the quality of services offered at institutions of higher education. The study was started at the beginning of the semester and conducted at the College of Business, University Utara Malaysia in the first semester of the 2015/2016 session. The group of respondents consisted of all the students who had registered for BWRS2013 "Risk Management and Takaful Planning". The lectures for the first semester began on $6^{\text {th }}$ September 2015 and ended on $19^{\text {th }}$ December 2015 excluding examination and holiday periods. The process of measuring the students' expectations and perceptions of the course during the semester was divided into three phases. Phase one was conducted at the end of the third week $\left(6^{\text {th }}-24^{\text {th }}\right.$ September 2015), phase two between the third to the sixth week (27 th September to $15^{\text {th }}$ October 2015), and the last phase fell between the seventh and the ninth week (18th October to $5^{\text {th }}$ November 2015$)$ shortly before the mid-semester break.

Procedures. In the first phase, normal lectures started as usual -- without the infusion of critical thinking into the syllabus. The curriculum and syllabus were adopted as designed and handed over to the researcher by the faculty management. Among the activities executed on the first day of the semester were the introduction of the syllabus and the requirements which needed to be fulfilled, such as attendance and the full semester calendar of scheduled quizzes and examinations as part of the assessment. Other grade requirements consisted of group research and presentation. The main lecture was conducted as a routine lecture where students barely contribute insignificantly or responded on a casual basis. In short a lecturer focus method. At the end of the third week, the first quiz was conducted as scheduled. The results were disappointing and seemed to justify the reports published by Nabilla (2015a, 2015b, 2015c) claiming that Islamic finance graduates were on average incompetent. The overwhelming majority of the students $(90 \%)$ achieved less than $50 \%$. Subsequently, the students were invited for consultation during their leisure periods. The results revealed that the syllabus did not prompt the students to think and reflect on the subject matter or encourage them to deepen their insight and apply their knowledge effectively and meaningfully. There were other factors that came to light, such as the fact that nearly all the students who had come for consultation confessed that they had not been sufficiently prepared for the quiz. Furthermore, they had not been able to cope with the given questions and realized that they were unable to connect the class discussion to real life events of risk and the best type of Takaful planning they should propose for their client.

The results of the first phase thus justified the subsequent infusion of critical thinking into the syllabus in the second phase. Critical thinking was introduced during the discussion to test the students' understanding of the subject matter and prompt them to apply their knowledge. Questions prompting discussion and critical thinking were deliberately invoked which challenged the students to provide immediate or temporary solutions. In addition, at the end of every class students were given additional mind tickling assignments in the form of idea generation to be discussed in the next class. After three weeks of intense coaching, the second quiz was conducted as scheduled. The results showed considerable improvement, with the large majority $(80 \%)$ of the students scoring above $75 \%$ and $17 \%$ of the student scored above $50 \%$. This most encouraging result prompted a further enquiry into the students' perception of their performance.

A refined SERVQUAL questionnaire developed by Parasuraman et al. (1991) was adapted for data collection. The pilot study questionnaire was administered to the respondents measuring the students' expectations and perceptions of the course, the mode of lecture and the lecturer's traits that they deemed most important. They were given the questionnaire on Tuesday and were asked to return it on Thursday. However, the questionnaire was structured in the language of risk management and Takaful planning. The pilot study's reliability result for expectation was 0.87 and perception was 0.85 which was above 0.80 
thresholds prescribed by Churchill (1979) as acceptable reliability. Therefore, the reliability of this study was justified.

In the third phase of the study, the same questionnaire was amended in terms of language clarifications and the addition of a section which measured the students' self-assurance. The modified SERVQUAL questionnaire was administered to the respondents after their mid-semester examination. The questionnaire was distributed to the respondents on $5^{\text {th }}$ November 2015 to be returned on $16^{\text {th }}$ November 2015. The class representative was deputized to collect the completed questionnaires on behalf of the researcher. This was to allow the respondents to provide sincere answers to the questions without any undue influence exerted by the present lecturer. The questionnaires remained anonymous as the respondents were not asked to give their names or matriculation numbers. All distributed questionnaires were returned. The average age of participants was 25 and out of the total participants, $15(35.71 \%)$ identified themselves as male and $27(64.29 \%)$ as female. Of the total of male students, one (2.38\%) was African, $11(26.19 \%)$ were Asians and three $(7.14 \%)$ were from the Middle East. Similarly, of the total of female students, two (4.76\%) were Africans and $25(59.52 \%)$ were Asians.

The final collected data were then analyzed by the statistical package of Smart Partial Least Square (SmartPLS). A partial least squares structural equation modelling was conducted and analyzed. According to Monecke and Leisch (2012), semPLS allows researchers to avoid covariance-based Structural Equation Modelling (SEM) when data are not symmetrical. Other advantages of SmartPLS are its efficiency in measuring scales in cases where the sample size is relatively small and contains residual distributions. In this study, the data or respondents were less than 50 which made semPLS conducted by SmartPLS a perfect choice.

Analysis of results. The reliability and internal consistency of the data set were first tested by conducting the reliability test to check for the goodness of fit. Table 1, the results showed Cronbach's Alpha (a) of assurance (.97), expectation (.97), and perception (.98). This indicates the per cent of variance the observed scale explained in the hypothetical true scale composed of all possible items in the total study. In other words, it can be viewed as the correlation of the observed scale with all possible other scales measuring the same objects and using the same number of items. The overall $R^{2}$ "R-Square" is ".81" achieving the conventional threshold set for an adequate data set that can be used in a standard inferential statistical calculation capable of policy formulation. These results support any conclusion that may be arrived at in this study. Although the number of participants has been limited, this research can serve as a basis for future research on a larger scale which examines the standardization of Islamic Finance education.

Table 1 - Reliability of Perception of Infused Critical Thinking into Syllabus

\begin{tabular}{|c|c|c|c|c|c|}
\hline & AVE & Composite Reliability & R Square & Cronbachs Alpha & Communality \\
\hline Assurance & 0.8514 & 0.9663 & 0.8113 & 0.9563 & 0.8514 \\
\hline Expectation & 0.5666 & 0.9657 & 0 & 0.9633 & 0.5666 \\
\hline Perception & 0.7293 & 0.9833 & 0 & 0.9821 & 0.7293 \\
\hline
\end{tabular}

Next was examined whether the relationship between assurance (dependent variable), expectation and perception was symmetrical or not. The central tendency, i.e. the mean $(\mathrm{M})$ and standard deviation $(\mathrm{SD})$ results showed that (expectation $\rightarrow$ assurance) $M=-0.059, \mathrm{SD}=0.049$. Similarly, (perception $\rightarrow$ assurance) $\mathrm{M}=0.94 \mathrm{SD}=0.028$. The mean with only little deviation indicated that students perception about the positive and significant effects of infusing critical thinking into the course, i.e. BWRS2013 "Risk Management and Takaful Planning". In other words, the students benefitted from their exposure to critical thinking and have become more capable and self-assured students of Islamic Finance. 
The Path Analysis (PA) results shown in Figure 1 reflect the overall relationships of the model. The relationship of the student's perception of assurance is positive 0.937 and significant as $t=33.732$ which falls above 1.96 at a $5 \%$ level of significance. This indicates that the students' perception of acquiring specific knowledge and other related skills were achieved through the successful infusion of critical thinking into the syllabus. Therefore, the infusion of critical thinking brought about significant positive effects on the students' level of self-assurance which is a pre-requisite for competency in a professional field, especially the one in question. Likewise, the relationship of students' expectation of assurance is negative -0.0639 and insignificant as $t=1.3094$ which is less than 1.96 at a $5 \%$ level of significance. This indicates that the students' expectation is lesser than what they finally gained from the infusion of the critical thinking into the syllabus. This was most likely the result of previous courses being organized in the normal lecturing mode which did not prompt the students to reflect and actively apply the subject content.

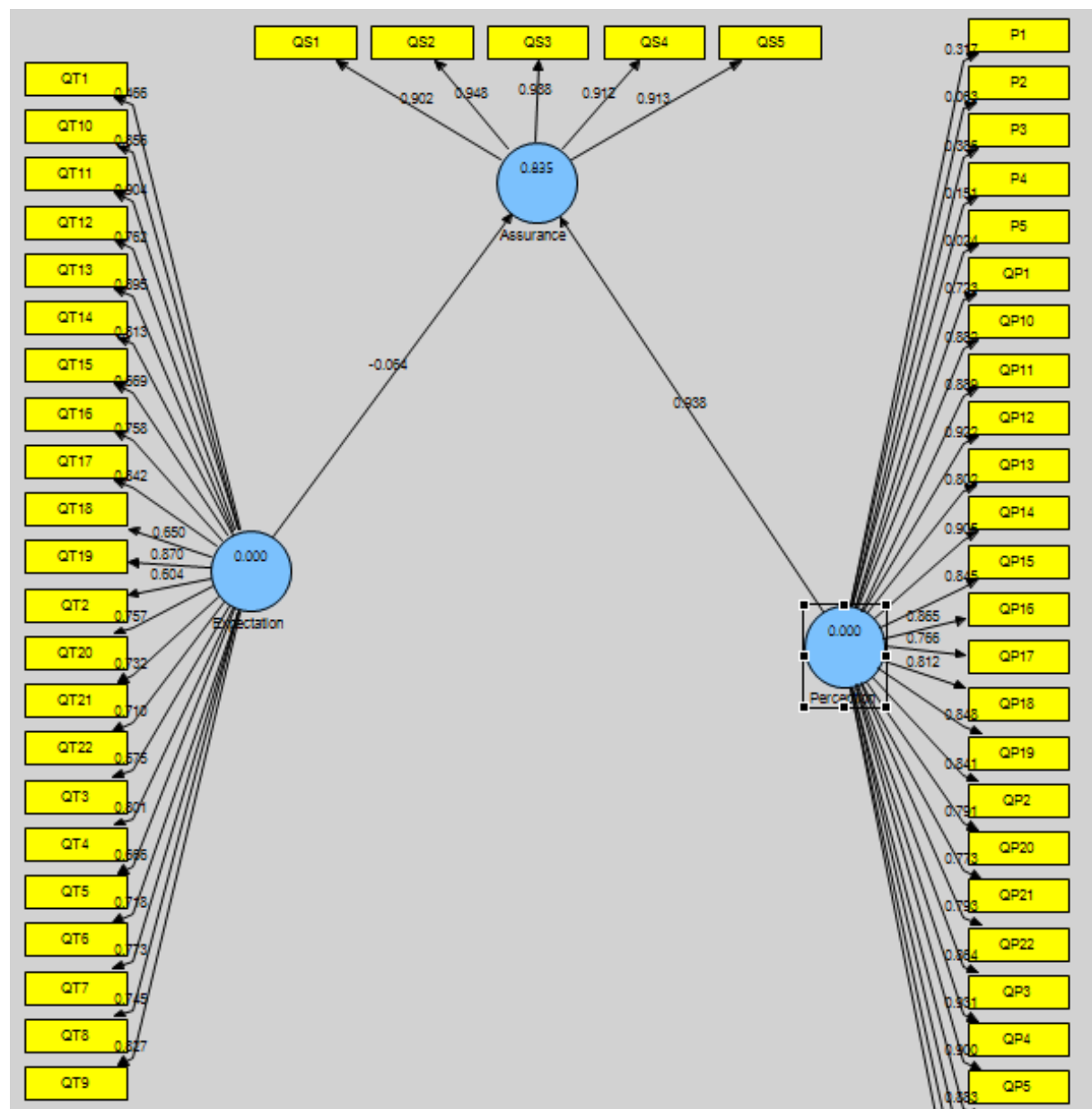

Figure 1 - Perceived Student Assurance through Infusion of Critical Thinking in the Syllabus

The findings of this study are consistent with the outcomes of previous studies such as Monroy-Licht, 
Collante-Padilla, González-Hernandez, 2016; Sanz Ponce et al., 2018 on the effectiveness of teaching people how to think critically. In the realm of educational psychology -- regardless of the numerous educational theories or approaches -- various methods of teaching critical thinking; one thing remains is, whether teaching it as a separate course or inclusion of critical thinking in an existing curriculum, have been debated. The positive and significant imprints of critical thinking in the educational system are evident in several previous studies Saarmann et al. 1992; Garrison, Anderson, and Archer, 2001; Lipman, 2003; Ku, 2009; Yang and Chung, 2009; Facione, 2011; Stassen, 2011; Hashemi and Ghanizadeh, 2012; Belcher et al., 2015, de Noyelles and Reyes-Foster, 2015; and Monroy-Licht, Collante-Padilla, GonzálezHernandez, 2016; Sanz Ponce et al., 2018. The majority of researchers, such as Thompson, 2011; Lin, 2014; Kloppers and Grosser, 2014; Aizikovitsh-Udi, Cheng, 2015; and Fuad et al., 2017 favour to incorporate critical thinking into the existing curricula rather than have it be taught separately. This allows students to interact and generate knowledge in the context of the area of discussion at their own pace. This constitutes a remarkable deviation from traditional teaching where knowledge is imparted to the passively absorbing students.

The teaching and learning of Islamic Finance are not exempted from this transformation. Humans are naturally characterized by intrinsic tendencies toward manipulation, distortion, error, etc. Thus, the current tendency of a lack of expertise in Islamic financial industry can be characterized as the segregated evolution of the Islamic finance and the customary western model. Islamic finance experts are mandated to master both the Islamic financial laws and transactions and the established western financial system operations, while some aspects are situated at the crossroads and pose a challenge.

The current lack of expertise in the Islamic banking and finance industry must have become apparent a few decades ago. However, it seems there seems to have been little or no strategies devised in order to respond to this challenge. The lack of critical thinking in the Islamic finance educational curriculum must have accounted for the incompetent experts graduating from higher institutions as Islamic Finance certificate holders. It is justified to argue here that the research and development unit of Islamic finance has overlooked or underestimated the role of critical thinking in this sector. Consequently, this failure hampered the development of manpower in the industry and may have also led to an over-reliance in the conventional finance experts when solving technical issues. The current situation, however, can be corrected by investing in research which focuses on incorporating critical thinking in the context of Islamic Finance across higher education institutions and private training centres.

Viewed from another perspective, any research and development (R\&D) should begin with training the lecturers/ and instructors specializing in the area of Islamic Banking and Finance in how to teach critical thinking in the context of their courses and specializations. This argument is based on the fact that a curriculum cannot work in isolation. Previous studies such as Emir (2013) and Fuad et al. (2017) found a significant relationship between the teachers' and students' critical thinking dispositions and thinking styles. The best curriculum could be redundant if the instructors lacked the knowledge of how to use it effectively to prompt their students to think independently. All lecturers and instructors of private and public higher institutions offering Islamic Finance as a program should undergo training in critical thinking. This step may prove particularly effective in all those countries which have heavily invested in this new Islamic financial system.

Discussion. Knowledge in the Lens of Capabilities. The capability is a holistic word that transcendent formal education in a specific profession. The capability is the anchor for acceptance of both animate and inanimate activities in worldly and supernatural affairs. Sanz Ponce et al. (2018) describes the complexity of Nussbaum's concept of capabilities. Nussbaum was described to have to distinguish between innate and internal capabilities. Innate capabilities are essential knowledge endowed on individuals, from the fetus until birth. Conclusively, a natural essence of human being distinguishes him/her from other creatures such as animal, insects etc. According to Nussbaum (2011), internal capabilities are 
features, training, and developing propensities through human interactions such as social, family, and political contacts which are termed as "basic capabilities".

A captivating analysis of human intellect, however, the separation between the innate, internal, and combine capabilities prolongs the most concise issue that has been solved by the Holy Prophet Muhammed \{peace and blessings of Allah be upon him\} almost 1500 years ago in some of his related traditions that signify priority of knowledge in life:

"Seek knowledge from the cradle to the grave."

Thus, acquisition of knowledge is a process and in stages which began from fetus where it learns how to adapt to the mother's womb such as feeding process, time to move, responding to different internal and external substances. These processes continue upon delivery, all infants share similar behaviours:

First, innate knowledge such as crying to indicate and inform the caregiver that something is wrong, as well as the act of mimicking close subjects and objects. In fact, this form of knowledge acquisition between day- 1 of an infant to a few early years continues and it is a general phenomenon regardless of ethnic, geographical, economic circumstances.

Second, the internal stage described by Nussbaum is, in fact, next stage to the infantry stage, where those general behaviours described above have to be reshaped through social, family, and political norms of the environment an individual life. At this stage, specific knowledge such as the method of alerting the caregiver of child's needs is developed e.g. speaking a specific language to some extent, eating etc.

The above points have been summarized again in one of the Holy Prophet Muhammed's traditions which further encourages and prioritize essentials of seeking knowledge:

"It was narrated from Anas bin Malik that the Messenger of Allah said: Seeking knowledge is a duty upon every Muslim, and he who imparts knowledge to those who do not deserve it, is like one who puts a necklace of jewels, pearls and gold around the neck of swines" (Sunan Ibn Majah, Book 1, Hadith 229)

In summary, these are basic knowledge that has sustained human existence since time immemorial. This is seeking knowledge from the cradle "mimicking period" until death which Nussbaum deemed need much focus than it has had in the past. She regarded this as human dignity. It is remarkable that contemporary scholars such as Nussbaum (2011) and "UN" UNESCO (2015) in particular recognize that knowledge is enshrined in "human dignity". This view underscores long-held and declared profound human dignity by the Prophet \{peace and blessings of Allah be upon him\} in another tradition which says:

"Knowledge is ornamental for men "humans"'

Education at the crossroad: Contention between economic benefits and human dignity. An intriguing aspect of Nussbaum (2011), UNESCO (2015) and Sanz Ponce et al. (2018) arguments is the trend in attention given to education. In addition to the modern method of delivering those knowledge discussed in the previous section, previous literature's concerns were mainly about inability and unguaranteed sustainability of human existence in the tattered educational system which wantonly ignores objectivity in the dissemination of knowledge. The results of these attitudes are incompetence, noncourageous, uninformed educated individuals that would result in the unintended destruction of a human generation.

One of the corrective measures raised by the UN (2015) is a global citizens' commitment to giving priority to 17 Sustainable Development Goal according to Agenda 2030 for Sustainable Development. For the sake of brevity, one major required action is to give value and dignity back to humans through sound education which is disseminated through easy, effective and friendly methods. This should be done with respect and dignity irrespective of ethnic, geographical location, disciplines "conventional or Islamic finance", and economic resources. Since Islamic finance education has been integrated into the global educational system, it suffices to examine current position based on the reports of IFN 2015 on growing incompetency among Islamic finance's graduates.

Educational Service and Satisfaction: a customer leaning. Previous literature such as Pereda, 
Airey and Bennett (2007), Hanaysha, Abdullah and Warokka (2011), Rasli, Shekarchizadeh and Iqbal (2012), Kontic (2014), Green (2014) and Yousapronpaiboon (2014) examines various aspects of students' satisfaction in regard to educational systems in Malaysia, Iran, Serbia, Thailand etc. by employing SERVQUAL reliability to measure college and university students' perspectives on their expectations of the services they were offered. Therefore, evaluation of students' satisfaction is deemed vital in arriving at a proper understanding of what is lacking in the Islamic finance education. In order to vindicate reason(s) why it seems to produce professionally incompetent graduates.

Several intuitive assumptions came to light identifying the probable cause for the inefficiency of the Islamic finance educational system. Among the assumptions include lack of sound curriculum, inadequate syllabus, inadequate lecturers etc. In addition, perhaps a hiding hindrance that has not been given keen attention is a lack of critical thinking embedded in the curriculum and cumbersome syllabus which need extra-time in delivery and assimilation processes on the part of lecturers and students respectively. Before adopting SERVQUAL in this present study, the researcher resolved to infuse critical thinking (CT) in the syllabus. Previous literature such as Nagappan (2001), Mimbs (2005), Fani (2011) and Dominguez et al. (2015) advocate importance of critical thinking (CT) skills as part of a dynamic curriculum and syllabus. The literature encouraged, in particular, the infusion of CT skills into the curriculum and syllabus even in engineering courses.

Against this background, it is important for Islamic finance educators to understand what students value in their study experience, whether they are local or overseas students. Although undergraduate and graduate students are given the chance to evaluate their learning and teaching experience in the form of end-of-semester evaluations, nonetheless, evaluations of the overall experience or overall quality of a specific program or mode of lecturing has remained rare or perhaps has not been given any serious attention in Islamic finance studies.

Conclusion. The findings have shown that investment in teaching Islamic Finance on part with critical thinking is of utmost importance for the success of the Islamic finance industry. Competent professionals are much needed in this field and will continue to remain an unfulfilled ideal if the current system of learning and teaching Islamic Finance continues as it is. The level of confidence and self-assurance of the students can only increase if students learn how to think critically and are capable of providing solutions to real-life problems. This study has shown that the regular graduates lacked expertise also lacked confidence in their own skills. This finding is supported by Anthone (2009) who concluded that philosophical and thus inquisitive talent is an important precondition for scientific education and training. This was confirmed by Fuad et al. (2017) results on the vital role of embedded critical thinking in the educational program. The results provided an incentive to consider the possible benefits of applying this model more widely in Islamic Finance curricula.

Participants in this study are limited to 42 students registered for BWRS2013 "Risk Management and Takaful Planning" enrolled in the same university. The considerably small sample may inspire similar studies in the future based on larger samples. A strong and healthy Islamic Finance industry has to be based on competent human capital, and not merely on stable finances. This, in turn, can enable a future generation of capable and independently thinking experts to truly integrate the Islamic financial system with the global financial system.

African Times (2018). IMF adopts CPIFR assessment standard for Islamic banking. May 25, retrieved June 9, 2018 , https://africatimes.com/2018/05/25/imf-adopts-cpiff-assessment-standard-for-islamic-banking/

Aizikovitsh, E., \& Amita, M. (2010). Evaluating an infusion approach to the teaching of critical thinking skills through mathematics. Procedia Social and Behavioral Sciences 2 (2010) 3818-3822

Aizikovitsh-Udi, E., \& Cheng, D. (2015). Developing Critical Thinking Skills from Dispositions to Abilities: Mathematics Education from Early Childhood to High School. Creative Education, 6, 455-462. http://dx.doi.org/10.4236/ce.2015.64045

Anthony, R. (2009). What about Thinking? The Inquisitive Mind and Philosophical Talent. 大阪大学大学教育実践センタ 一紀要. 6, Pp.33-41. http://hdl.handle.net/11094/7633 
Annuar, N. (2015a). Human Capital: What does the industry really need? Vol. 1(1), May. Pp. 1-2. Retrieved 15 November 2015 , www.ifneducation.com

Annuar. N. (2015b). Human capital: A mounting demand in the industry. Vol.1(3), September. Pp. 1-3. Retrieved 15 November 2015, www.ifneducation.com

Annuar, N. (2015c). A recruiter's perspective: An insight into the requirements of the Malaysian Islamic finance job market. Islamic Finance News, Vol. 1(3), September. Pp. 4-5. www.ifneducation.com

Annuar, N. (2015d). Rising demand for Islamic finance credentials signals the start of an improvement. Islamic Finance News,

Vol. 1(5), November. Retrieved 15 November 2015, www.ifneducation.com/issue/volume-1-issue-5

Annuar, A. (2015e). The dearth in Islamic finance. Vol. 1(1), May, p.3. Retrieved 15 November 2015, www.ifneducation.com

Belcher, A. R., Hall, B. M., Kelley, K. \& Pressey, K. L. (2015). An Analysis of Faculty Promotion of Critical Thinking and Peer Interaction within Threaded Discussions. Online Learning, Vol.19(4), pp. 27-44.

deNoyelles, A., Reyes-Foster, B. (2015). Using Word Clouds in Online Discussions to Support Critical Thinking and Engagement. Online Learning, Vol.19(4), pp.13-24.

Dominguez, C., Nascimento, M. M., Payan-Carreira, R., Cruz, G., Silva, H., Lopes, J., Morais, M. da F. A. \& Morais, E. (2015). Adding value to the learning process through online peer review activities: towards the elaboration of a methodology to promote critical thinking in future engineers. European Journal of Engineering Education, Vol. 40(5), pp.573-591

Emir, S. (2013). Consultancy and Research Center www.edam.com.tr/estp Contributions of Teachers' Thinking Styles to Critical Thinking Dispositions (Istanbul-Fatih Sample). Educational Sciences: Theory \& Practice, 13(1), pp. 337-347.

Facione, P. A. (2011). Critical Thinking: What It is and Why it Counts. Insight Assessment: Millbrae, CA: Measured Reasons and The California Academic Press. Retrieved 16 March 2016

Fani, T. (2011). Overcoming Barriers to Teaching Critical Thinking. 1st international conference on the Future of Education, Florence, Italy, June 16-17.

Fuad, N.M., Zubaidah, S., Mahanal, S., \& Suarsini, E. (2017). Improving Junior High Schools' Critical Thinking Skills Based on Test Three Different Models of Learning. International Journal of Instruction, 10(1), pp. 101-116.

Garrison, D. R., Anderson, T \& Archer, W. (2001). Critical thinking, cognitive presence, and computer conferencing in distance education. American Journal of Distance Education, Vol. 15(1), pp.7-23, DOl: 10.1080/08923640109527071

Green, P. (2014). Measuring Service Quality in Higher Education: A South African Case Study. Journal of International Education Research, Vol. 10(2), pp. 131-142.

Hanaysha, J. R. M., Abdullah, H. H. \& Warokka, A. (2011). Service Quality and Students' Satisfaction at Higher Learning Institutions: The Competing Dimensions of Malaysian Universities' Competitiveness. Journal of Southeast Asian Research Vol. 2011 (2011). DOI: 10.5171/2011.855931. http://www.ibimapublishing.com/journals/JSAR/jsar.html

Hashemi, M. R., \& Ghanizadeh, A. (2012). Critical discourse analysis and critical thinking: an experimental study in an EFL context. System, 40(1), 37-47.

Islamic Finance News (2018). IMF to develop alternative assessment criteria for Islamic banking. May 28, retrieved May 28 ,

2018, www.IslamicFinancenews.com

Kloppers, M. \& Grosser, M. (2014). The Critical Thinking Dispositions of Prospective Mathematics Teachers at a South African University: New Directions for Teacher Training. Int. J Edu Sci., 7(3): 413-427.

Kontic, L. (2014). Measuring Service Quality in Higher Education: The Case of Serbia. International Conference on Human Capital without Boarders: Management, Knowledge and Learning for Quality of Life. 25-27, Portoroz, Slovenia International Conference. Retrieved 16 March 20, 2016, www.toknowpress.net/ISBN/978-961-6914-09-3/.../ML14-610.pdf

Ku, K. Y. L. (2009). Assessing students' critical thinking performance: Urging for measurements using a multi-response format. Thinking Skills and Creativity, 4, 70-76.

Lai, E. R. (2011). Critical Thinking: A Literature Review. A Pearson Research Report, Retrieved, 16 March 2016.

Lin, Y. (2014). Infusion of Critical Thinking into L2 Classes: A Case Study in a Chinese High School. Thesis Submitted for the Degree of Doctor of Philosophy, Integrated PhD in Education and Applied Linguistics, Newcastle University. Retrieved 16 March 2016, https://theses.ncl.ac.uk/dspace/bitstream/10443/2377/1/Lin,\%20Y.\%2014.pdf

Lipman, M. (2003). Thinking in Education (2nd Eds.). Cambridge: Cambridge University Press

Mimbs, C. A. (2005). Teaching from the critical thinking, problem-based curricular approach: strategies, challenges, and recommendations. Journal of Family and Consumer Sciences Education, 23(2), 7-18.

Maurer, B. (2010). Form versus substance: AAOIFI projects and Islamic fundamentals in the case of Sukuk. Journal of Islamic Accounting and Business Research, 1(1), 32-41.

Monecke, A. \& Leisch, F. (2012). semPLS: Structural Equation Modeling Using Partial Least Squares. Journal of Statistical Software, Vol. 48(3), pp.1-32, http://www.jstatsoft.org/

Monroy-Licht, A., Collante-Padilla, A., \& González-Hernandez, R. (2016). An Environmental Management Project: Situated Learning to Enhance Critical Thinking Skills in College Students. Transformative Dialogues: Teaching \& Learning Journal, Vol. 8(3), pp.1-13.

Nagappan, R. (2001). The Teaching of High-Order Thinking Skills in Malaysia. Journal of Southeast Asian Education, Vol. 2(1), pp.1-21.

Nussbaum,M.C.(2011).Creating Capabilities. London: The Belknap Press of Harvard University Press.

http://mmi.fem.sumdu.edu.ua/en 
Pereda, M., Airey, D., \& Bennett, M. (2007). Service quality in overseas education: The experience of overseas students. Journal of Hospitality, Leisure, Sport and Tourism Education, 6(2), 55-67.

Sanz Pounce, R., Paris Cancio, J.S., \& Sanchez Gordella, J.E (2018). The Capabilities Approach and Values of Sustainability: Towards and Inclusive Pedagogy. Journal of Innovation \& Knowledge, (3), pp. 76-81.

Rasli, A., Shekarchizadeh, A., \& Iqbal, M. J. (2012). Perception of Service Quality in Higher Education: Perspective of Iranian Students in Malaysian Universities. International Journal of Academic Research in Management, Vol. 1(1), pp. 10-25

Saarmann, L., Freitas, L., Rapps, J., \& Reigel, B. (1992). The relationship of education to critical thinking ability and values among nurses: Socialization into professional nursing. Journal of Professional Nursing, Vol. 8(1), pp. 26-34. DOI: http://dx.doi.org/10.1016/8755-7223(92)90114-E

Shep, S. J., Sheehan, M., \& McKinley, D. (2013). Exploring Digital Technologies and Historical Thinking in undergraduate learning and teaching at VUW. Wellington: Victoria University Report. Retrieved 16 March 2016, www.victoria.ac.nz/...thinking/Report-

Stassen, M. L. A., Herrington, A., \& Henderson, L. (2011). Defining Critical Thinking in Higher Education: Determining Assessment Fit. Improve the Academy, Judith Miller, editor. Vol. 30, pp.126-141.

Thompson, C. (2011). Critical Thinking across the Curriculum: Process over Output. International Journal of Humanities and Social Science, Vol. 1(9), pp. 1-7.

Yang, S. C. \& Chung, T. (2009). Experimental study of teaching critical thinking in civic education in Taiwanese junior high school. British Journal of Educational Psychology, 79, 29-55

Yousapronpaiboon, K. (2014). SERVQUAL: Measuring higher education service quality in Thailand. Procedia - Social and Behavioral Sciences 116(2014), pp. 1088-1095.

Л. А. Олорогун, Ph.D., Вищий коледж технологій, (Абу-Дабі, Об'єднані Арабські Емірати);

Н. Юнуса, Університет Ахмаду Белло Заріа (Заріа, Нігерія);

Х. Г. Ауду, Міжнародний ісламський університет Султан Абдул Халім Муадзам Шах (Кедах, Малайзія);

A. A. Мухаммед, Ph.D., Малазійський університет Саравак (Сарвак, Малайзія).

Менеджмент освітніх інновацій: поширення "критичного мислення" у навчальних програмах фінансових дисциплін серед ісламських країн

у роботі висувається гіпотеза, що впровадження в навчальні програми критичного мислення підвищує якість просресійних знань і забезпечує набуття студентами впевненості у своїх навичках, що є запорукою профресійного успіху. Авторами було проаналізовано результати впровадження критичного мислення в навчальний план BWSR2013 "Управління ризиками та планування". Перевірка гіпотези здійснювалася на основі отриманих даних у ході опитування. Використовуючи SemPLS на платформі SmartPLS отримано дані, які свідчать, що відсутність критичного мислення в навчальних програмах призводить до зниження кількості кваліфікованих фрахівців у фінансовому секторі. Результати дослідження підтверджують наявність тісної кореляиії між набутими знаннями, компетентностями та критичним мисленням. Результати аналізу особистісного сприйняття студентами знань показали, що критичне мислення сприяє підвищенню їх самовпевненості у набутих знання. Так, автори підтверджують гіпотезу, що критичне мислення повинно бути невід'ємною складовою навчальних програм, у тому числі при викладанні фінансових дисциплін для студентів ісламських країн. У рамках дослідження автори аналізують та систематизують можливі переваги від впровадження «критичного мислення» в навчальні програми студентів-фінансистів при вивченні фінансових дисциплін серед ісламських країн. Виявлено зв'язок між зростанням фінансового сектору та обсягом інвестицій в освітній процес з елементами критичного мислення. Автори наголошують на необхідності подальших досліджень даної проблеми, розширивши вибірку для аналізу. На основі результатів дослідження автори стверджують, що рівень впевненості студентів збільшується за умови набуття ними навичок критичного мислення і здатності вирішувати реальні фінансові проблеми.

Ключові слова: знання, сприйняття, критичне мислення, студенти, можливості, навчальна програма. 